\title{
Occurrence of Capillaria sp. in the liver of sheep (Ovis aries) in a slaughterhouse in the state of Acre, Brazil
}

\author{
Ocorrência de Capillaria sp. em fígado de ovino (Ovis aries) em um abatedouro no estado do Acre, Brasil \\ Paulo Eduardo Ferlini Teixeira ${ }^{1}$; Christiane Leal Corrêa ${ }^{2,3}$; Fernanda Bittencourt de Oliveira ${ }^{4}$; \\ Alba Cristina Miranda de Barros Alencar ${ }^{4,5}$; Leandro Batista das Neves ${ }^{4}$; Daniel Daipert Garcia ${ }^{4}$; \\ Fernanda Barbosa de Almeida ${ }^{4}$; Luis Cláudio Muniz Pereira ${ }^{2,3}$; José Roberto Machado-Silva ${ }^{5}$; \\ Rosângela Rodrigues-Silva ${ }^{4 *}$

\begin{abstract}
${ }^{1}$ Instituto Federal do Acre - IFAC, Xapuri, AC, Brasil
${ }^{2}$ Departamento de Patologia, Faculdade de Ciências Médicas, Centro Biomédico, Universidade do Estado do Rio de Janeiro - UERJ, Rio de Janeiro, RJ, Brasil

${ }^{3}$ Escola de Medicina, Universidade Estácio de Sá - Estácio, Rio de Janeiro, RJ, Brasil

${ }^{4}$ Laboratório de Helmintos Parasitos de Vertebrados, Instituto Oswaldo Cruz - IOC, Fundação Oswaldo Cruz - Fiocruz, Rio de Janeiro, RJ, Brasil

${ }^{5}$ Laboratório de Helmintologia Romero Lascasas Porto, Departamento de Microbiologia, Imunologia e Parasitologia, Faculdade de Ciências Médicas, Centro Biomédico, Universidade do Estado do Rio de Janeiro - UERJ, Rio de Janeiro, RJ, Brasil
\end{abstract}

Received October 25, 2017

Accepted March 19, 2018

\begin{abstract}
Although sheep farming has grown in the state of Acre over the past four decades, little is known about occurrences of helminthiases in the herds of this region. The objective of the study was to assess the occurrences of non-intestinal helminthiasis among sheep slaughtered in Rio Branco. A total of 110 sheep livers were inspected from two slaughter batches (july 2014 and march 2015) in a slaughterhouse in Rio Branco. Livers with macroscopic lesions were photographed and were then subjected to histopathological analysis under an optical microscope. The macroscopic lesions showed small nodes with inflammatory characteristics and areas of fibrosis, which appeared to be calcified, thus suggesting a granulomatous reaction. Of the 110 evaluated livers, we noticed 110 nodules in total; these nodules have an average size of $0.5 \mathrm{~cm}$. The histopathological analysis showed alterations to the architecture of the hepatic lobe, with multiple foci of necrosis and polymorphonuclear cells. Two samples revealed the presence of helminths from Nematode class and Capillaria sp. eggs identified by the typical morphology and morphometry. This seems to be the first report of Capillaria sp. in sheep livers in Brazil, and it serves as an important alert regarding animal health surveillance and control and regarding the Capillaria sp. zoonotic role in humans.

Keywords: Histopathology, hepatic lesions, helminths, nematodes, bright-field microscope, Amazon rainforest.
\end{abstract}

\section{Resumo}

Embora a ovinocultura tenha despertado o interesse de criadouros no estado do Acre nas últimas quatro décadas, pouco se conhece sobre a ocorrência de helmintoses no plantel de ovinos dessa região. O objetivo do presente estudo foi avaliar a possibilidade de ocorrência de helmintíases não intestinais entre ovinos abatidos no município de Rio Branco. Foram inspecionados 110 fígados de ovinos em dois abates (julho de 2014 e março de 2015) em um abatedouro no município de Rio Branco. Fígados com lesóes macroscópicas foram fotografados com posterior análise histopatológica por microscopia de luz. Nas lesóes macroscópicas foram encontrados pequenos nódulos apresentando características inflamatórias com áreas de fibrose, aparentemente calcificadas, sugerindo uma reação granulomatosa. Dos 110 fígados avaliados, observou-se 110 nódulos no total; estes nódulos têm um tamanho médio de $0,5 \mathrm{~cm}$. A análise histopatológica mostrou alteraçóes na arquitetura do lóbulo hepático, com múltiplos focos de necrose, além da formação de abscessos hepáticos constituídos por polimorfonucleares. Duas amostras revelaram a presença de helmintos da Classe Nematoda e ovos de Capillaria sp. identificados pela morfologia típica e morfometria. Esse resultado parece ser o primeiro registro de Capillaria sp. em fígado de ovino no Brasil, o que é um importante alerta para a vigilância no controle sanitário animal e o seu papel zoonótico para humanos.

Palavras-chave: Histopatologia, lesóes hepáticas, helmintos, nematóides, microscopia de campo claro, floresta Amazônica.

*Corresponding author: Rosângela Rodrigues-Silva. Laboratório de

Helmintos Parasitos de Vertebrados, Instituto Oswaldo Cruz - IOC, Fundação

Oswaldo Cruz - Fiocruz, Av. Brasil, 4365, Manguinhos, CEP 21045-900, Rio

de Janeiro, RJ, Brasil. e-mail: rsilva@ioc.fiocruz.br; hidatidose@ioc.fiocruz.br 


\section{Introduction}

Sheep farming has been shown to be an attractive investment in developing countries (LEROY et al., 2015). Brazil has followed this trend with herds distributed mainly in the northeastern and southern portions of the country (RIBEIRO \& GONZÁLEZ-GARCÍA, 2016). Over the past four decades (1985-2015) there has been high growth in the northern region of Brazil (IBGE, 2015), particularly the use of the Santa Inês breed because of its high productivity and hardiness (RIBEIRO \& GONZÁLEZ-GARCÍA, 2016).

Helminthiases are the main causes of loss of production in sheep herds (MACIEL, 2014). The nematode Haemonchus contortus is the most epidemiologically important gastrointestinal helminth among sheep in tropical and subtropical regions in the world (MAVROT et al., 2015). Data from Brazil confirm the importance of $H$. contortus (CARDOSO et al., 2012; ATAÍDE \& CANSI, 2013; FERREIRA et al., 2015; VIEIRA et al., 2014; WILMSEN et al., 2014), particularly for the Santa Inês breed of sheep in the state of Rio Grande do Norte (SOUZA et al., 2012). On the other hand, ruminants may also be infected by other gastrointestinal nematodes that are considered to be less epidemiologically important, such as Capillaria bovis Schnyder, 1906. This species has been reported in cervids in France (JUSTINE \& FERTÉ, 1988, 1989), Canada (DIES \& COUPLAND, 2001) and Turkey (BOLUKBAS et al., 2012), wild deer in Norway (DAVIDSON et al., 2014) and sheep in India (JAIN \& KAMLAPUR, 1969).

In Brazil, infection by C. bovis (syn. Aonchotheca bovis) (FREITAS \& MENDONÇA, 1961) was reported in cattle in different states, and specifically in the small intestine of Ovis aries in the microregion of Jaboticabal, in the northwestern region of the state of São Paulo (MACIEL, 2014). Although capillarids have a wide range of mammal hosts (rodents, lagomorphs, ruminants, birds, canids, fishes, non-human primates and humans), data from the literature show that these are predominantly parasites of rodents (FUEHRER, 2014a). Moreover, zoonotic potential has been reported as particularly relevant for $C$. hepatica (FUEHRER, 2014b) and C. bovis in ruminants in Poland (GAŁĘCKI et al., 2015).

Definitive hosts become infected by ingesting embryonated eggs spread into the environment. First stage larvae (L1) hatched in the small intestine, migrate via the portal system to the liver, where adults worms mate. Gravid females lay hundreds of unembryonated eggs in the surrounding liver parenchyma, which are unable to leave the host (true infection). The life cycle progression requires the death of the host, in which decomposed liver releases unembryonated eggs into the environment. The alternative transmission pathway includes predators, scavengers and cannibals animals, which also release unembryonated eggs. Because such nematodes are soil-transmitted helminths, unembryonated eggs require environmental factors (soil texture, $\mathrm{pH}$ and temperature) to progress to the embryonic stage (GONÇALVES et al., 2012).

Over the last decades, a novel mode of transmission has been reported, when humans feed meat of wild mammals in Brazil (CAMARGO et al., 2010; KLISIOWICZ et al., 2014; QUADROS et al., 2016). Eggs pass away the gut and are released in stool similar to predators (spurious infection) (COIMBRA \& MELLO, 1981; SOARES et al., 2011; FUEHRER, 2014a).

Liver capillariasis is characterized by small milky spots, focally distributed in the surface or parenchyma. The histopathological features include hepatic granuloma and eventually fibrosis (ANDRADE \& ANDRADE, 2004; JEONG et al., 2008; GABAN et al., 2010). However, little is known about the histopathological situation of natural capillarid infections among ruminants (NAKAMURA, 2005). These last authors used the term parasitic bovine hepatitis for multiple small lesions with fragments of worms similar to capillarids. Their report was similar to what was described for rodents naturally infected by C. hepatica (JEONG et al., 2008; SINGLA et al., 2013; MOREIRA et al., 2013). Similar to other dwelling-liver helminth (Fasciola hepatica and metacestodes of tapeworms), the inspection of carcasses of meat could detect cases of capillariasis (UNGAR et al., 1990; TESSELE et al., 2013).

The objective of the present study was to assess the possibility of occurrences of non-intestinal helminthiasis among sheep slaughtered in the municipality of Rio Branco, the capital of the state of Acre.

\section{Materials and Methods}

Sheep livers $(n=162)$ were inspected for the presence of macroscopic lesions at a slaughterhouse in the municipality of

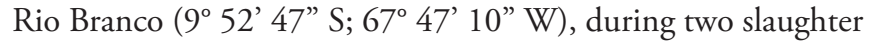
batches (July 2014 and March 2015). This slaughterhouse, which is located in the state capital, receives animals from the municipalities of Rio Branco, Bujari, Sena Madureira, Feijó, Senador Guiomard, Capixaba, Acrelândia, Plácido de Castro, Porto Acre, Xapuri, Brasiléia and Epitaciolândia (Figure 1).

The animals were slaughtered in accordance with the regulations governing humane slaughter. The macroscopic evaluation of the livers took place after a sanitary evaluation. Livers that presented alterations were photographed using a digital camera (Nikon, model DS-Fi1, China), fixed in 10\% neutral formalin and sectioned into pieces. Routine histopathological processing of the samples and histopathological analyses were conducted at the Laboratory for Helminth Parasites of Vertebrates of the Oswaldo Cruz Institute (FIOCRUZ, Rio de Janeiro) and at the Romero Lascasas Porto Helminthology Laboratory of the State University of Rio de Janeiro (UERJ).

Slides were stained with hematoxylin and eosin (H\&E) and picrosirius. The histopathological analysis on the material was carried out using a bright-field microscope (Nikon, model Eclipse E200, China). The images were processed in a digital image analyzer equipped with the Nis Elements AR software (Nikon, USA).

Capillaria sp. eggs that were found in the hepatic parenchyma were subjected to morphometric analysis (total length and width), considering the shape of the eggs and the bulge of polar plugs. The morphometric analysis was performed through an ocular micrometer (Nikon, China). All the measures found were compared with those already existing in the scientific literature (FUEHRER, 2014b). 

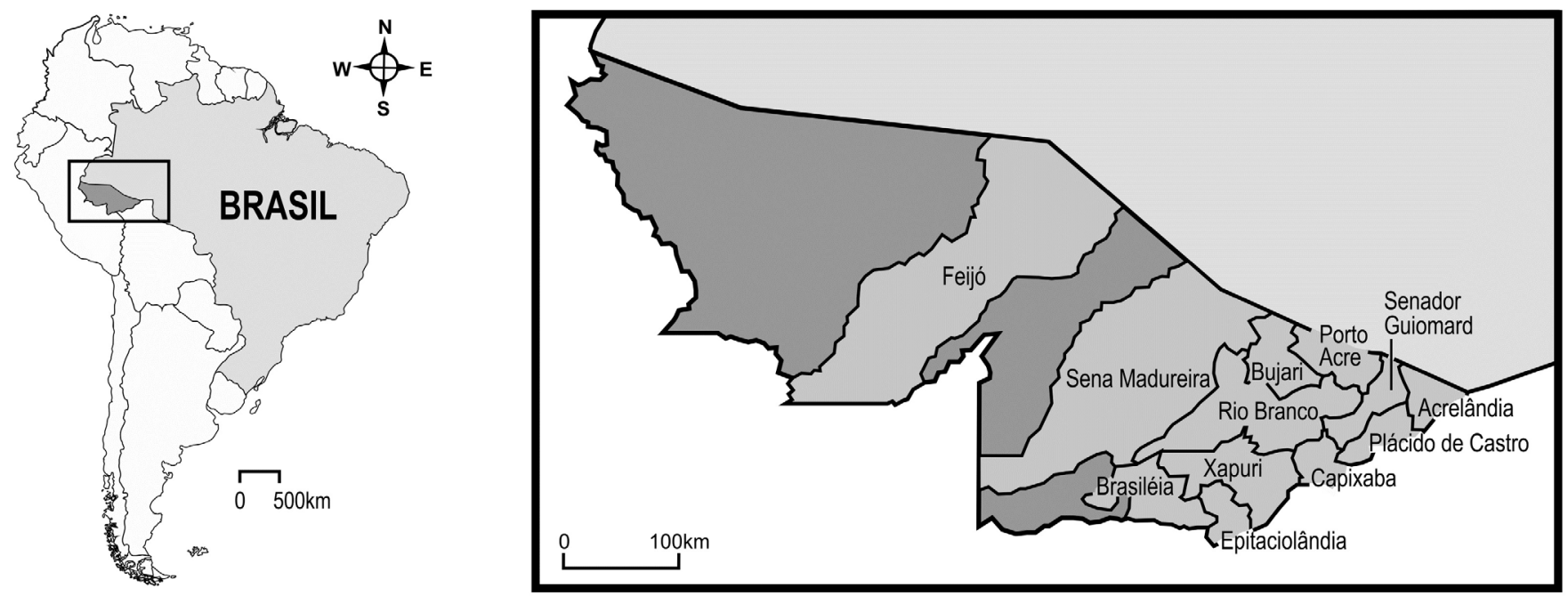

Figure 1. Municipalities from where the sheep at the slaughterhouse in the city of Rio Branco, Acre, Brazil, originated. Source: Illustration produced by Heloisa Diniz, Image Treatment and Production Service, IOC/Fiocruz-RJ, Brazil.

\section{Results}

Among the 162 animals slaughtered, the livers of 110 animals (67.9\%) presented macroscopic lesions, of which $63(57.2 \%)$ were in males and $47(42.7 \%)$ were in females. The macroscopic lesions in the macroscopic evaluation, well delimited masses were observed presenting elevations to the external surface of the liver, irregular, little encapsulated, firm and subcapsular, about $2-5 \mathrm{~cm}$ in diameter with a grayish-white coloration, therefore, lighter than the liver around them (Figure 2A).

The histopathological findings of the presence of Capillaria sp. showed a variety of results from the disintegration of the parasite and the presence of its eggs in the liver. In regions close to the eggs of the parasite, necrotic-inflammatory focal lesions with lympho-histoplasmacytic and multifocal eosinophilic infiltrate were observed (Figures 2B-D).

Other histopathological findings, dispersed in the hepatic parenchyma and linked to the presence of Capillaria sp., were verified: presence of pseudolobules formed by groups of hepatocytes with strings arrangement without defined lobular architecture, surrounded by fibrous tissue originating from the portal spaces, containing numerous proliferative bile ducts, multiple necrosis foci, in addition to the formation of hepatic abscesses, consisting of polymorphonuclear cells, with poorly delimited and irregular margins (Figure 2B).

We observed a necrotic central lesion, distributed in several areas in the hepatic parenchyma, suggesting debris of Capillaria sp. and / or remains of dead eggs, characterizing a granulomatous reaction. Dystrophic calcification can be observed in some necrotic central lesions and the presence of palisade cells around the granulomatous reactions, especially in those that did not yet present fibrous encapsulation (Figure 2C).

The histological sections revealed the presence of cylindrical helminths, with a pseudocoelom, a muscle layer in the body wall with longitudinal fibers, a covering cuticle and a triradiate pharynx, thus indicating a representative of the phylum Nematoda (Figures 2D, E).

The hepatic parenchyma of one sample presented a cluster of eggs of the genus Capillaria sp., which presented an oval shape, striated capsule and non-profuse bipolar operculum (Figure 2F). The morphometry of the eggs $(\mathrm{n}=10)$ indicated variations in length between 47.5 and $50 \mu \mathrm{m}$ (mean: $48.5 \pm 1.29 \mu \mathrm{m}$ ) and in width between 22.5 and $25 \mu \mathrm{m}$ (mean: $24.5 \pm 1.05 \mu \mathrm{m}$ ).

Other histopathological findings, bridged portal fibrosis, thick septa of connective tissue, frequently connecting a portal space to another, formation of long thin fibrous septa overlying the central vein between them, accumulation of fat in the form of rounded globules of varying sizes in the hepatocyte cytoplasm, classified as macro and microsteatosis. In addition, chronic inflammatory mononuclear tissue composed of macrophages, lymphocytes and fibroblasts was found, delimited by a fibrous capsule, characterizing a granulomatous reaction.

\section{Discussion}

The objective of the present study was to assess the possibility of occurrences of non-intestinal helminthiasis among sheep slaughtered in the municipality of Rio Branco, the capital of the state of Acre. Over the past four decades there has been a significant increase in sheep farming in this region and the animals slaughtered in Rio Branco originated from several municipalities in this state.

Macroscopic hepatic lesions characterized as small inflammatory nodules with areas of fibrosis, which appeared to be calcified, were suggestive of the presence of granulomas. Although hydatidosis and fasciolosis are included in this situation (ROBERTS, 1982; VECHIATO et al., 2011), there were no indications of infection by these parasitic agents in the present study. On the other hand, macroscopic hepatic lesions are a common finding among rodents that are naturally infected by $C$. hepatica (JEONG et al., 2008; SINGLA et al., 2013; MOREIRA et al., 2013). Microscopically, 

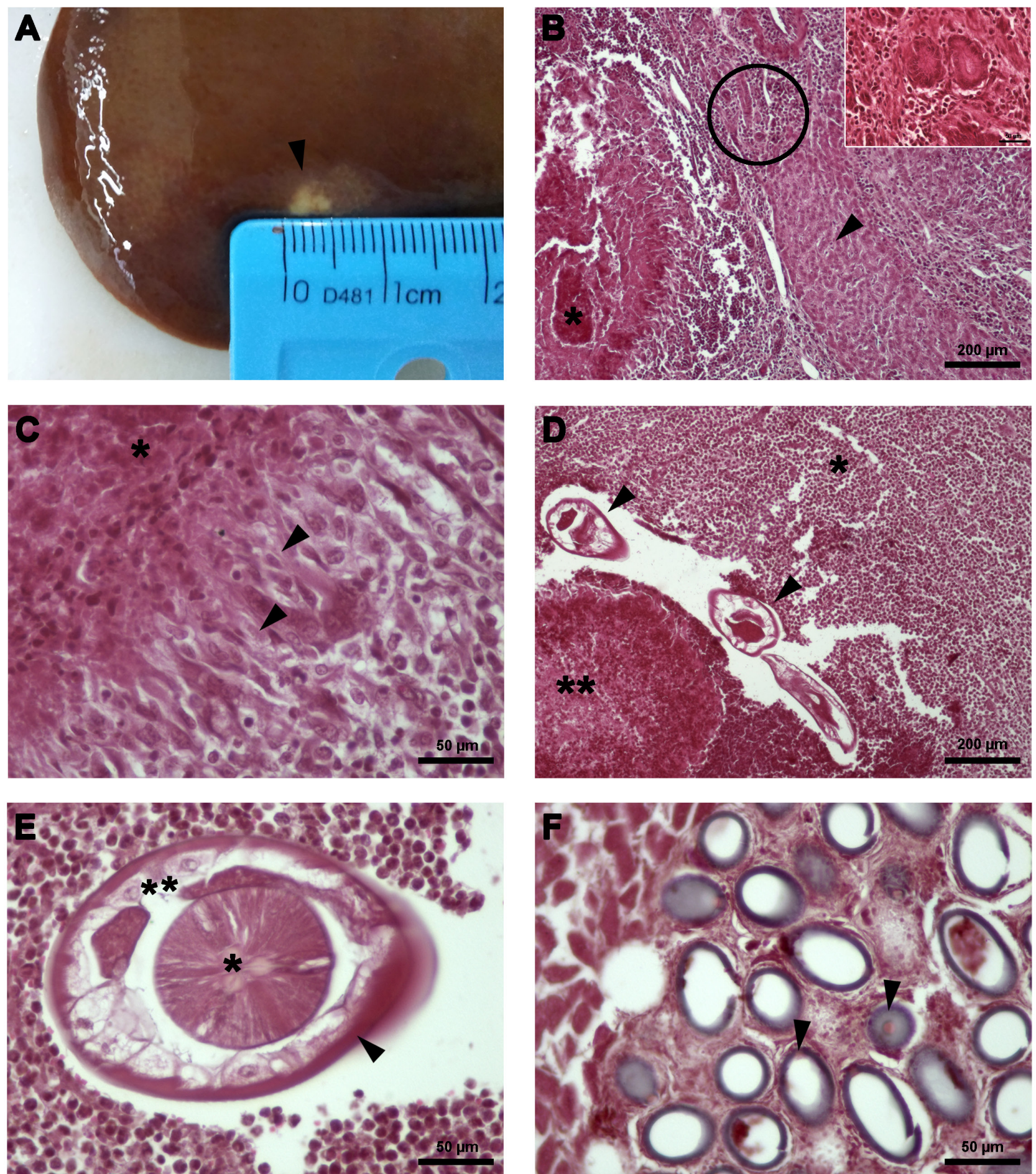

Figure 2. Liver of Ovis aries infected by Capillaria sp. (A) Macroscopic lesion (granuloma) (arrow); (B) Hepatic parenchyma with calcified granuloma $(*)$, ductal proliferation (circle and insite) and pseudolobules (arrow) (H\&E, 100X); (C) Necrosis $\left(^{*}\right)$ and palisade cells (arrows) (H\&E, 400X); (D) Hepatic parenchyma with leukocyte infiltration $\left(^{*}\right)$, coagulative necrosis $\left(^{* *}\right)$ and a section through a nematode helminth (arrow) (H\&E, 100X); (E) Detail of the helminth showing the muscle layer of the body wall (arrow), triradiate pharynx $\left(^{*}\right)$ and pseudocoelom $\left.{ }^{(* *}\right)$ (picrosirius, 400X); (F) Cluster of Capillaria sp. eggs (arrow) (H\&E, 400X).

the alterations to the hepatic parenchyma of rodents range from inflammatory lesions to fibrotic lesions (ANDRADE \& ANDRADE, 2004; JEONG et al., 2008; GABAN et al., 2010). Moreover, nematode fragments and clusters of $C$. hepatica eggs have also been observed, which are common findings in rodent infections (MOREIRA et al., 2013). Likewise, sections from bovine hepatic tissue have revealed possible infection by Capillaria sp. (NAKAMURA, 2005).

Capillarids are known to present complex taxonomy because of their wide diversity of hosts, including rodents (FUEHRER, 2014a; 
SIMÓES et al., 2014; WALKER et al., 2017) and other mammals (FUEHRER, 2014b). Occurrences of C. bovis have been reported in the gastrointestinal tract of ruminants (JUSTINE \& FERTÉ, 1988, 1989; DIES \& COUPLAND, 2001; BOLUKBAS et al., 2012; DAVIDSON et al., 2014; MACIEL, 2014). In contrast to these findings, the present study revealed the presence of hepatic infection in two sheep, possibly caused by $C$. hepatica (syn. Calodium hepaticum), which presents low host specificity and high liver tropism. There is a report of Agouti paca (paca) naturally infected by $C$. hepaticum from the municipality of Bujari (state of Acre) (ALMEIDA et al., 2013). Other studies have also shown infections among synanthropic rodents (Rattus norvegicus and Rattus rattus) in Belém, in the eastern Amazon region (MOREIRA et al., 2013).

The ecology of capillariasis should be highlighted. Both adult worms and unembryonated eggs are located in the liver of definitive hosts, from which they can not be disposed. However, the parasite evolved two transmission pathways which indirectly overcome this barrier. First, decomposed liver from dead hosts liberate eggs in the environment. The other strategy includes predators, scavengers and cannibals animals, which release unembryonated eggs in the feces. Because some capillarids are soil-transmitted helminth, the life cycle progresses when unembryonated eggs find adequate conditions for development (soil texture, $\mathrm{pH}$ and temperature) and eggs become embryonated or infective (GONÇALVES et al., 2012). It is likely that the ground was contaminated with eggs released from synanthropic and wild rodents (MOREIRA et al., 2013; ALMEIDA et al., 2013). Although liver capillariasis due to C. hepaticum in ovine has never been previous reported in Brazil, the inspection ovine meat for human consumption should be carried out to avoid the potential risk for humans (UNGAR et al., 1990; TESSELE et al., 2013). In addition, other studies are required to evaluate a possible impact on the sheep production.

\section{Conclusion}

Thus, this first report of Capillaria sp. among sheep in the state of Acre is of great importance from a public health point of view. It indicates that there is a need for the Institute of Agricultural and Forestry Sanitary Protection (IDAF) to develop preventive actions in relation to the current management strategies for sheep farming in this state, so as to avoid increased occurrences of this parasitosis among herds in the state of Acre and also contamination among human populations.

\section{Acknowledgements}

The authors are grateful to Heloisa Diniz from the Image Treatment and Production Service - IOC/Fiocruz-RJ, Brazil, for producing the map presented.

\section{References}

Almeida F, Caldas R, Corrêa C, Rodrigues-Silva R, Siqueira N, MachadoSilva JR. Co-infections of the cestode Echinococcus vogeli and the nematode
Calodium hepaticum in the hystricomorphic rodent Agouti paca from a forest reserve in Acre, Brazil. J Helminthol 2013; 87(4): 489-493. http:// dx.doi.org/10.1017/S0022149X12000661. PMid:23072769.

Andrade SB, Andrade ZA. Experimental hepatic fibrosis due to Capillaria hepatica infection (Differential features presented by rats and mice). Mem Inst Oswaldo Cruz 2004; 99(4): 399-406. http://dx.doi.org/10.1590/ S0074-02762004000400010. PMid:15322630.

Ataide HS, Cansi ER. Occurrence of parasitic diseases in sheep and goats in the District Federal, Brazil, during 2003 to 2009. Arq Inst Biol 2013; 80(3): 342-345.

Bolukbas CS, Gurler AT, Beyhan YE, Acici M, Umur S. Helminths of roe deer (Capreolus capreolus) in the Middle Black Sea Region of Turkey. Parasitol Int 2012; 61(4): 729-730. http://dx.doi.org/10.1016/j. parint.2012.06.008. PMid:22766455.

Camargo LM, Aranha Camargo JSA, Vera LJS, Barreto PTC, Tourinho EK, Souza MM. Capillariaisis (Trichurida, Trichinellidae, Capillaria hepatica) in the Brazilian Amazon: low pathogenicity, low infectivity and a novel mode of transmission. Parasit Vectors 2010; 3(1): 11. http:// dx.doi.org/10.1186/1756-3305-3-11. PMid:20187941.

Cardoso CP, Cardozo LL, Silva BF, Amarante AFT. Gastrointestinal parasites in goats from Monte Castelo, Santa Catarina, Brazil. Rev Bras Parasitol Vet 2012; 21(2): 148-150. http://dx.doi.org/10.1590/S198429612012000200014 . PMid:22832756.

Coimbra CE Jr, Mello DA. Enteroparasitas e Capillaria sp. entre o grupo Surui, Parque Indigena Aripuana, Rondonia. Mem Inst Oswaldo Cruz 1981, 76(3): 299-302. http://dx.doi.org/10.1590/S0074-02761981000300008. PMid:7348780.

Davidson RK, Kutz SJ, Madslien K, Hoberg E, Handeland K. Gastrointestinal parasites in an isolated Norwegian population of wild red deer (Cervus elaphus). Acta Vet Scand 2014; 56(1): 59. http://dx.doi.org/10.1186/ s13028-014-0059-x. PMid:25294401.

Dies KH, Coupland RW. Prevalence of gastrointestinal helminths in domestic bison herds in northwestern Alberta. Can Vet J 2001; 42(4): 295-296. PMid:11326634.

Ferreira RC, Nascimento-Junior AB, Santos PJ, Botter-Carvalho ML, Pinto TK. Responses of estuarine nematodes to an increase in nutrient supply: an in situ continuous addition experiment. Mar Pollut Bull 2015; 90(1-2): 115-120. http://dx.doi.org/10.1016/j.marpolbul.2014.11.012. PMid:25499965.

Freitas JFT, Mendonça JM. Novo capilariíneodo gênero Aonchotheca López-Neyra, 1947 (Nematoda, Trichuroidea). Mem Inst Oswaldo Cruz 1961; 59(1): 59-63. http://dx.doi.org/10.1590/S0074-02761961000100006.

Fuehrer HP. An overview of the host spectrum and distribution of Calodium hepaticum (syn. Capillaria hepatica): part 1-Muroidea. Parasitol Res 2014a; 113(2): 619-640. http://dx.doi.org/10.1007/s00436-0133691-x. PMid:24248632.

Fuehrer HP. An overview of the host spectrum and distribution of Calodium hepaticum (syn. Capillaria hepatica): part 2-Mammalia (excluding Muroidea). Parasitol Res 2014b; 113(2): 641-651. http:// dx.doi.org/10.1007/s00436-013-3692-9. PMid:24257974.

Gaban L, Ramos CD, Barbosa AA Jr, Souza MM, Andrade ZA. Dynamics of Capillaria-hepatica-induced hepatic septal fibrosis in rats. Rev Soc Bras Med Trop 2010; 43(6): 643-646. http://dx.doi.org/10.1590/S003786822010000600008 . PMid:21181015. 
Gałęcki R, Sokol R, Koziatek S. Parasites of wild animals as a potential source of hazard to humans. Ann Parasitol 2015; 61(2): 105-108. PMid:26342506.

Gonçalves AQ, Ascaso C, Santos I, Serra PT, Julião GR, Orlandi PP. Calodium hepaticum: household clustering transmission and the finding of a source of human spurious infection in a community of the Amazon region. PLoS Negl Trop Dis 2012; 6(12): e1943. http://dx.doi.org/10.1371/ journal.pntd.0001943. PMid:23285301.

Instituto Brasileiro de Geografia e Estatística - IBGE. Censo agropecuário [online]. Rio de Janeiro: IBGE; 2015 [cited 2017 May 25]. Available from: http://www.sidra.ibge.gov.br/bda/pecua/default.asp?z=t\&o=24\&i=P

Jain PC, Kamlapur SK. Occurence of Capillaria bovis Schnyder, 1906 in sheep in India. Indian Vet J 1969; 46(11): 1010-1011. PMid:5389781.

Jeong W, Do S, Hong I, Ji A, Park J, Ki M, et al. Macrophages, myofibroblasts and mast cells in a rat liver infected with Capillaria hepatica. J Vet Sci 2008; 9(2): 211-213. http://dx.doi.org/10.4142/ jvs.2008.9.2.211. PMid:18487945.

Justine JL, Ferté H. Redescription de Capillaria bovis (Schnyder, 1906) (Nematoda, Capillariinae). Bull Mus Natl Hist Nat 1988; 10(4): 693-709.

Justine JL, Ferté H. Capillaria bovis (Nematoda, Capillariinae) parasite du Mouflon, du Daim et du Chevreuil en France: liste des hôtes dans le Monde. Bull Mus Natl Hist Nat 1989; 11(1): 79-96.

Klisiowicz DR, Reifur L, Shimada MK, Haidamak J, Cognialli RC, Ferreira T. High occurrence of Calodium hepaticum (syn. Capillaria hepatica) spurious infection in a village in the Atlantic Forest of southern Brazil. Mem Inst Oswaldo Cruz 2014; 109(3): 371-373. http://dx.doi. org/10.1590/0074-0276140315. PMid:24676661.

Leroy JL, Ruel M, Frongillo EA, Harris J, Ballard TJ. Measuring the food access dimension of food security: a critical review and mapping of indicators. Food Nutr Bull 2015; 36(2): 167-195. http://dx.doi. org/10.1177/0379572115587274. PMid:26121701.

Maciel WG. Prevalência de nematódeos em ovinos (Ovis aries) pertencentes a diferentes microrregióes do Estado de São Paulo, Brasil [dissertation]. Jaboticabal: Faculdade de Ciências Agrárias e Veterinárias, Universidade Estadual Paulista; 2014

Mavrot F, Hertzberg H, Torgerson P. Effect of gastro-intestinal nematode infection on sheep performance: a systematic review and meta-analysis. Parasit Vectors 2015; 8(1): 557. http://dx.doi.org/10.1186/s13071-0151164-z. PMid:26496893.

Moreira VLC, Giese EG, Silva DCB, Melo FTV, Furtado AP, Maldonado A Jr, et al. Calodium hepaticum (Nematoda: Capillariidae) in synanthropic rodents (Rattus norvegicus and Rattus rattus) in Eastern Amazonia. Rev Bras Parasitol Vet 2013; 22(2): 265-269. http://dx.doi.org/10.1590/ S1984-29612013000200046. PMid:23856730.

Nakamura N. Parasitic lesion of bovine liver attributed to Capillaria species. J Comp Pathol 2005; 132(2-3): 228-231. http://dx.doi.org/10.1016/j. jcpa.2004.08.001. PMid:15737350.

Quadros RM, Weiss PH, Miletti LC, Moura AB. Occurrence of Calodium hepaticum (Bancroft, 1893) Moravec, 1982 eggs in feces of dogs and cats in Lages, Santa Catarina, Brazil. Rev Inst Med Trop 2016; 58(0): 6. http://dx.doi.org/10.1590/S1678-9946201658006. PMid:26910455.
Ribeiro ELA, González-García E. Indigenous sheep breeds in Brazil: potential role for contributing to the sustainability of production systems. Trop Anim Health Prod 2016; 48(7): 1305-1313. http://dx.doi. org/10.1007/s11250-016-1109-3. PMid:27393314.

Roberts JL. The prevalence and economic significance of liver disorders and contamination in grain-fed and grass-fed cattle. Aust Vet J 1982; 59(5): 129-132. http://dx.doi.org/10.1111/j.1751-0813.1982.tb02756.x. PMid:6891898.

Simôes RO, Luque JL, Faro MJ, Motta E, Maldonado A Jr. Prevalence of Calodium hepaticum (Syn. Capillaria hepatica) in Rattus norvegicus in the urban area of Rio de Janeiro, Brazil. Rev Inst Med Trop São Paulo 2014; 56(5): 455-457. http://dx.doi.org/10.1590/S0036-46652014000500016. PMid:25229230.

Singla N, Singla LD, Gupta K, Sood NK. Pathological alterations in natural cases of Capillaria hepatica infection alone and in concurrence with Cysticercus fasciolaris in Bandicota bengalensis. J Parasit Dis 2013; 37(1): 16-20. PMid:24431534.

Soares MCP, Nunes HM, Silveira FAA, Alves MM, Souza AJS. Capillaria hepatica (Bancroft, 1893) (Nematoda) entre populaçóes indígenas e mamíferos silvestres no noroeste do Estado do Mato Grosso, Brasil, 2000. Rev Pan-Amaz Saude 2011; 2(3): 35-40. http://dx.doi.org/10.5123/ S2176-62232011000300005.

Souza MF, Pimentel-Neto M, Silva RM, Farias ACB, Guimarães MP. Gastrointestinal parasites of sheep, municipality of Lajes, Rio Grande do Norte, Brazil. Rev Bras Parasitol Vet 2012; 21(1): 71-73. http://dx.doi. org/10.1590/S1984-29612012000100015. PMid:22534950.

Tessele B, Brum JS, Barros CSL. Parasitic lesions observed in cattle slaughtered for human consumption. Pesq Vet Bras 2013; 33(7): 873-889. http://dx.doi.org/10.1590/S0100-736X2013000700008.

Ungar BL, Burris JA, Quinn CA, Finkelman FD. New mouse models for chronic Cryptosporidium infection in immunodeficient hosts. Infect Immun 1990; 58(4): 961-969. PMid:2108092.

Vechiato TAF, Maschio W, Bom LC, Lopes PD, Ortolani EL. Estudo retrospectivo de abscessos hepáticos em bovinos abatidos em um frigorífico paulista. Braz J Vet Res Anim Sci 2011; 48(5): 384-391. http://dx.doi. org/10.11606/S1413-95962011000500005.

Vieira VD, Feitosa TF, Vilela VL, Azevedo SS, Almeida JL No, Morais DF, et al. Prevalence and risk factors associated with goat gastrointestinal helminthiasis in the Sertão region of Paraíba State, Brazil. Trop Anim Health Prod 2014; 46(2): 355-361. http://dx.doi.org/10.1007/s11250013-0496-y. PMid:24214525.

Walker R, Carvalho-Pereira T, Serrano S, Pedra G, Hacker K, Taylor $\mathrm{J}$, et al. Factors affecting carriage and intensity of infection of Calodium hepaticum within Norway rats (Rattus norvegicus) from an urban slum environment in Salvador, Brazil. Epidemiol Infect 2017; 145(2): 334-338. http://dx.doi.org/10.1017/S0950268816002259. PMid:27780498.

Wilmsen MO, Silva BF, Bassetto CC, Amarante AFT. Gastrointestinal nematode infections in sheep raised in Botucatu, state of São Paulo, Brazil. Rev Bras Parasitol Vet 2014; 23(3): 348-354. http://dx.doi.org/10.1590/ S1984-29612014058. PMid:25271455. 